\title{
OS DOIS LADOS DA MOEDA: PANAMBY E CITY JARAGUÁ, EXEMPLOS DA FRAGMENTAÇÃO DO ESPAÇO URBANO PAULISTANO ${ }^{1 .}$
}

\author{
Adriano Botelho*
}

\section{RESUMO:}

Segundo o filósofo Henri Lefebvre, o espaço produzido sob o domínio das relações de produção capitalistas é marcado pela fragmentação, homogeneização e hierarquização. O presente artigo analisa dois casos aparentemente opostos de provisão habitacional no município de São Paulo, mas que dada a lógica de reprodução do capital que se materializa no espaço e domina a sua produção e reprodução, apresentam alguns traços em comum na relação com o seu entorno. Ou seja, será explorada a ideia de que a racionalidade do modo capitalista de produção e as contradições da sociedade se combinam para a produção de um espaço que é segregado e segregador, cujas positividades e negatividades são vividas no cotidiano por seus moradores em graus que possuem relação com seu nível socioeconômico, mas cujo resultado final é um todo que parece ser menor que a soma das partes.

\section{PALAVRAS-CHAVE:}

Fragmentação do espaço; segregação socioespacial; urbano; Bairro Panamby; City Jaraguá.

\section{ABSTRACT:}

Two sides of the same coin: Panamby and City Jaraguá, examples of fragmentation of the urban space in the city of São Paulo.

According to the philosopher Henri Lefebvre, the space produced by the capitalist relationships is marked by fragmentation, homogenization and hierarchizing. The present article analyses two cases of housing in the city of São Paulo apparently opposed but which have some points in common with respect of their relationships with their neighborhood due to the dominance of the capital's logic in production and reproduction of space. It will be explored the idea that the rationality of the capitalist mode of production and the contradictions of society are combined to produce a space that is segregated and segregator, which positivities and negativities are lived in the quotidian by their inhabitants in ways that vary according to their socio-economical level, but whose final outcome is a whole that seems to be minor than the sum of their parts.

\section{KEY-WORDS:}

Fragmentation of space; socio-spatial segregation; urban; Bairro Panamby; City Jaraguá.

\section{Introdução}

Nos gustaba la casa porque aparte de espaciosa y antigua (hoy que las casas antiguas sucumben a la mas ventajosa liquidación de sus materiales) guardaba los recuerdos de nuestros bisabuelos, el abuelo paterno, nuestros padres y toda la infancia.

(...)
Lo recordaré siempre con claridad porque fue simple y sin circunstancias inútiles. Irene estaba tejiendo en su dormitorio, eran las ocho de la noche y de repente se me ocurrió poner al fuego la pavita del mate. Fui por el pasillo hasta enfrentar la entornada puerta de roble, y daba la vuelta al codo que llevaba a la cocina cuando escuché algo en el comedor o en la biblioteca. El sonido venia impreciso y sordo,

${ }^{*}$ Mestre e Doutor em Geografia Humana pela Faculdade de Filosofia, Letras e Ciências Humanas da Universidade de São Paulo. Atualmente participa do Projeto Temático "Urbanização Dispersa e Novas Formas de Tecido Urbano" do LAP-FAU-USP. Endereço eletrônico: abot@usp.br. 
como un volcarse de silla sobre la alfombra o un ahogado susurro de conversación. También lo oí, al mismo tiempo o un segundo después, en el fondo del pasillo que traía desde aquellas piezas hasta la puerta. Me tire contra la pared antes de que fuera demasiado tarde, la cerré de golpe apoyando el cuerpo; felizmente la llave estaba puesta de nuestro lado y además corrí el gran cerrojo para más seguridad.

Fui a la cocina, calenté la pavita, y cuando estuve de vuelta con la bandeja del mate le dije a Irene:

- Tuve que cerrar la puerta del pasillo. Han tomado la parte del fondo. Dejó caer el tejido y me miró con sus graves ojos cansados.

- ¿Estás seguro?

Asentí.

- Entonces - dijo recogiendo las agujas tendremos que vivir en este lado.

(Casa Tomada, Julio Cortazar, 1994).

O Conto Casa Tomada de Júlio Cortázar pode ser interpretado - entre tantas outras leituras possíveis - como uma metáfora do que está acontecendo com as cidades, não só no Brasil, como em todo o mundo. A segregação socioespacial se faz cada vez mais presente por meio dos processos de valorização imobiliária e de fragmentação, homogeneização e hierarquização do espaço urbano. Os habitantes das cidades não são somente expulsos das suas áreas mais valorizadas, mas também da própria cidade e do que Henri Lefebvre chamou de as positividades do urbano (LEFEBVRE, 1999). A reclusão em condomínios fechados, nos shopping centers, nos automóveis particulares são efeitos de uma concepção que vê na cidade algo que não mais pertence aos seus moradores, nem aos mais abonados - que tentam fugir dos crescentes perigos que a cidade passa a representar para eles -; nem aos mais pobres, que por sua vez, não possuem acesso a essas positividades, sendo "depositados" nas periferias distantes do consumo, do trabalho e do lazer, ou separados dos ricos por muros e outros tipos de barreiras cada vez mais visíveis na paisagem urbana. Cabe a seus habitantes a escolha entre retomar a casa, ou seja, apropriarem-se da cidade em que vivem, ou se conformarem com o fato de que ela foi tomada pelo capital e seus agentes (imobiliários, financeiros, etc.).

O espaço, ao longo da história do modo de produção capitalista, passou a fazer parte dos circuitos de valorização do capital, seja pela mercantilização da terra, seja pelo seu parcelamento (pelo loteamento ou pela verticalização), ou, como vem ocorrendo mais recentemente, pela sua crescente inclusão nos circuitos de circulação do capital financeiro. A produção do espaço passa a ser um elemento estratégico para a acumulação do capital. Segundo Henri Lefebvre (1999), escrevendo em 1970, ocorreria uma crescente dependência por parte do capitalismo da produção e consumo do espaço nas últimas décadas. A relação entre o espaço (sua produção, vivência, percepção, concepção e conceituação) e o modo capitalista de produção deve ser vista, porém, como uma via de mão dupla, como fazendo parte de uma relação dialética e complexa.

De forma mais abrangente, a produção e o consumo do espaço, assim como a urbanização, estão inseridos no amplo processo de reprodução das relações de produção capitalistas, na medida em que são guiados pelos ditames da propriedade privada e são regulados pelas necessidades do capital de gerar valor excedente. Segundo Lefebvre:

não é somente a sociedade inteira quem se torna o lugar da reprodução (das relações de produção e não somente dos meios de produção), mas é o espaço inteiro. Ocupado pelo neocapitalismo, setorializado, reduzido a um meio homogêneo e, portanto, fragmentado, esmigalhado (somente migalhas do espaço são vendidas à 'clientela'), o espaço se torna a sede do poder (LEFEBVRE, 1973, p. 116).

O espaço - e em particular o espaço urbano - passa, então, a ter cada vez maior importância para o capital, ao mesmo tempo em que é "influenciado" pela dinâmica do modo de produção capitalista. A predominância do financeiro nas estratégias de acumulação 
capitalistas tem a produção do espaço como uma das condições de sua realização (CARLOS, 2004).

Dessa forma, o espaço, consumido produtivamente nas estratégias de acumulação capitalista é transformado, tem suas qualidades alteradas pelo consumo, porém, possui a capacidade de, ao ser transformado, também transformar e produzir o novo; como nos lembra Henri Lefebvre, o consumo do espaço é duplamente produtivo na medida em que produz tanto mais-valia quanto outro espaço (LEFEBVRE, $2000)^{2}$. Por sua vez, a crescente integração subordinada do espaço nas estratégias de acumulação do capital acarreta uma produção de um espaço cada vez mais marcado pela tríade lefebvriana, ou seja, pela fragmentação, pela homogeneização e pela hierarquização espaciais.

Para Lefebvre (1980), por homogeneização entende-se a repetição monótona de elementos no espaço e que conformam tal espaço: aeroportos, vias expressas, rodovias, cidades verticais de concreto, cidades horizontais de casas unifamiliares etc., criando um consumo repetitivo de coisas no espaço e do espaço que engendra um tédio indelével. É um espaço produzido para ser visto, com suas características ópticogeométricas. Esse espaço homogeneizado é também o lócus de ligação das relações capitalistas mundializadas, com seus pontos fortes (os centros) e as bases mais frágeis e dominadas (as periferias).

Segundo o mesmo autor, a fragmentação relaciona-se com o espaço partido em espaços separados, ocupados pelas funções que se exercem nesses espaços distintos: trabalho, moradia, lazeres, transportes, produção, consumo. "O espaço - como o trabalho - se torna parcelado: justaposição de parcelas fixadas a uma atividade parcial no qual o conjunto, o processo do habitar, escapa aos participantes" (LEFEBVRE, 1980 , p. 154). Rigidamente quantificado, medido em metros quadrados, como em dinheiro, esse espaço "fatiado" é entregue ao mercado em parcelas, quase sempre mínimas. Não se trata somente da atomização do social em indivíduos separados, em individualidades hostis e desprezíveis, mas sim da divisão quase sem limites do "continente" da sociedade, continente que não é indiferente ao conteúdo, é o suporte das relações sociais. Dessa forma a fragmentação é um instrumento de poder político, pois "separa para reinar", transformando os membros da sociedade em indivíduos indiferentes entre si, unidos em grupos de interesses contrapostos, isolados por barreiras visíveis e invisíveis.

E por fim, os espaços dissociados no homogêneo se hierarquizam: espaços nobres e vulgares, espaços residenciais, espaços funcionais, guetos diversos, conjuntos de alto padrão, áreas para os migrantes e para os autóctones, espaços das classes médias. Em resumo, segundo Lefebvre (1980), ocorre a segregação. A hierarquização toma formas gerais e específicas: a distinção entre os "pontos fortes" do espaço e os centros (de poder, de riqueza, de trocas materiais ou espirituais, de lazeres, de informação) e as periferias (elas também hierarquizadas, mais ou menos afastadas de um centro principal ou secundário, até tomar a forma de um lugar deserto, abandonado). A dominação dos centros sobre os espaços dominados garantiria o caráter homogêneo do espaço.

Esse processo triádico de fragmentação, homogeneização e hierarquização do espaço apontaria para o surgimento da não-cidade (ou anticidade; Lefebvre, 1991,1999), na medida em que intensificaria a segregação socioespacial no urbano, criando obstáculos para o encontro e a reunião de pessoas, para o consumo coletivo de objetos, de idéias etc. Ou seja, à medida que o valor de uso subordina-se ao valor de troca e a mercadoria generaliza-se no urbano, a cidade e a realidade urbana tendem a ser destruídas (LEFEBVRE, 1991), pois a cidade não é vivida em sua totalidade, e sim fragmentariamente e através de crescentes constrangimentos a seus habitantes.

Dessa forma, a segregação socioespacial parece ser a regra na maior parte das cidades. As parcelas mais abonadas da população urbana crescentemente buscam o isolamento em áreas fechadas (loteamentos ou condomínios fechados, shopping centers, centros empresariais e 
complexos de escritórios), fenômeno presente na metrópole de São Paulo, mas não restrito à realidade brasileira, como se pode observar em Los Angeles, Berlim, Nova York, Buenos Aires, Lagos, Nairobi, Cidade do México, Xangai, Bombaim, Calcutá, entre outras cidades do mundo ${ }^{3}$.

Por outro lado, a população mais pobre é segregada em áreas mais distantes ou nos interstícios das áreas centrais das metrópoles contemporâneas, mas que são pouco valorizadas (beira de córregos, encostas, áreas de instabilidade geológica etc. $)^{4}$, onde falta a maior parte da infraestrutura e dos equipamentos urbanos.

O presente artigo tem por objetivo aplicar a análise tríadica acima proposta ao caso da metrópole de São Paulo com base em dois casos aparentemente em tudo contrapostos: o Bairro Panamby e o Mutirão City Jaraguá. Dessa forma, buscaremos mostrar como realidades tão distintas em termos socioeconômicos podem se aproximar nas relações que seus moradores possuem com o entorno que os cerca, pois o processo de isolamento e segregação decorrente da tríade fragmentação-homogeneização-hierarquização abarca toda a sociedade. Claro está que as diferentes camadas de renda da população possuem acessos diferenciados às possibilidades oferecidas pelo urbano, e isso também será objeto de análise no presente artigo. Porém, devemos ter em conta que a racionalidade do modo capitalista de produção e as contradições da sociedade se combinam para a produção de um espaço que é fragmentado, hierarquizado, homogeneizado, segregado e segregador, cujas positividades e negatividades são vividas no cotidiano por seus moradores em graus que possuem relação com seu nível socioeconômico, mas cujo resultado final é um todo que parece ser menor que a soma das partes.

Os dois casos analisados refletem os extremos sócio-econômico-espaciais da metrópole paulista. O Bairro Panamby é um empreendimento residencial de alto padrão numa das áreas de maior valorização imobiliária da metrópole paulistana (o chamado "vetor sudoeste", CARLOS, 2004), sendo a síntese da integração entre o mercado financeiro com o setor imobiliário, um caso exemplar de área urbana autossegregada e de marketing do setor imobiliário. Já o mutirão City Jaraguá localiza-se na periferia noroeste do município de São Paulo, área pobre e distante da centralidade urbana, fruto de anos de lutas do movimento por moradia. Não é difícil perceber o que separa essas duas realidades. $O$ que surpreende é o que as aproxima.

O presente artigo é fruto de mais de três anos de pesquisa bibliográfica e documental, bem como da realização de entrevistas com agentes imobiliários urbanos e seus representantes, arquitetos, funcionários das companhias habitacionais que atuam na metrópole paulistana e moradores dos empreendimentos em questão.

Nos próximos itens serão caracterizados os dois empreendimentos, pois cada um, a seu modo, representa uma inovação na provisão da moradia na metrópole de São Paulo. Em seguida são apresentadas as considerações finais, por intermédio da análise da fragmentação do espaço urbano e da autossegregação das comunidades estudadas.

\section{O Bairro Panamby}

A área na qual o Bairro Panamby foi projetado possui uma história peculiar. Trata-se de uma grande gleba (cerca de $482.215 \mathrm{~m}^{2}$ ) denominada Chácara Tangará, localizada no vetor de maior valorização imobiliária da cidade de São Paulo (vetor sudoeste), próxima à Marginal Pinheiros, entre as Pontes João Dias e Morumbi, e que contava com uma cobertura vegetal secundária em avançado estágio de recuperação, com várias espécies de vegetação (pau-ferro, jequitibá, jacarandá paulista, ipês, embaúba, quaresmeira, etc.), que a caracterizava como sendo um dos últimos testemunhos representativos da Mata Atlântica dentro da área urbana do município de São Paulo. A área conta também com uma nascente de um córrego que deságua no Rio Pinheiros, caracterizando-se, até a década de 1990, como um raro exemplo de curso d'água não poluído no município de São 
Paulo. A área, ainda, contava com edificações históricas: uma casa de taipa do século XIX e uma residência inacabada projetada pelo arquiteto Oscar Niemeyer, datada de 1955, cujo jardim foi projetado pelo paisagista Burle Max.

O terreno, parte de uma antiga fazenda, foi propriedade da rica família Pignatari. Nos idos da década de 1950, Baby Pignatari (Francisco Pignatari) imaginara uma mansão de sete mil metros quadrados desenhada por Oscar Niemeyer e com jardins traçados por Burle Marx, que incluía piscinas e uma sala de projeção para 500 pessoas. Para tanto, entre 1952 e 1957 ele comprou os terrenos dos antigos proprietários da área, como membros das famílias Oliveira, Almeida, José Mello Alves, Júlio Bouquet, entre outros, sendo que a última parcela (de $84.456 \mathrm{~m}^{2}$ ) formadora da gleba atual foi adquirida por ele bem mais tarde, em 1968, sendo de propriedade da então Light - Serviços de Eletricidade S.A. (herdeira da São Paulo Tramway, Light and Power Company, Limited $)^{5}$. Porém, Pignatari se desinteressou pelo projeto sem ter concluído as obra da mansão e o terreno ficou sem uso até ser comprado pela Lubeca S.A. do Espólio de Francisco Pignatari em 1986. A Lubeca era uma empresa ligada ao Moinho Santista Indústrias Gerais, que por sua vez pertencia ao grupo argentino Bunge \& Born. Essa empresa planejava desenvolver no local um ambicioso projeto envolvendo de 10 a 12 torres de escritórios e de 30 a 35 edifícios de apartamentos de alto padrão, com 20 andares cada um, além de um hotel cinco estrelas, avaliado em cerca de 600 milhões de dólares na década de 1980, para uma área construída de aproximadamente $600 \mathrm{mil} \mathrm{m}^{2}$. Associada à Lubeca estava a construtora e incorporadora Birmann S.A., que comprou cerca de $1 / 4$ do terreno em $1986^{6}$.

Tal área foi rebatizada pela Lubeca como Panamby, que quer dizer em tupi-guarani "borboleta azul", em referência à quantidade de borboletas na área e a um projeto da Lubeca, na época do lançamento do empreendimento imobiliário, de criar um berçário de borboletas nativas da região. Tratava-se já de uma estratégia de marketing que se tornou a marca do Panamby: a associação do projeto com a "natureza".
Porém, dados seus atributos naturais, históricos e arquitetônicos e tendo em vista a ação de desmatamento realizada pela Lubeca, a área em questão teve seu tombamento pedido por um grupo de entidades profissionais e de classe e por alguns políticos paulistas junto ao CONDEPHAAT (Conselho de Defesa do Patrimônio Histórico, Arqueológico, Artístico e Turístico do Estado).

A empresa Lubeca alegava, na época do pedido de tombamento, que havia realizado os Estudos de Impacto Ambiental (EIA/RIMA) devidamente aprovados pelo IBAMA (Instituto Brasileiro do Meio Ambiente e dos Recursos Naturais Renováveis) e pelo CONSEMA (Conselho de Avaliação de Relatórios de Impacto Ambiental) em abril de 1989, bem como o de uso e ocupação do solo requeridos, e que o projeto havia sido aprovado pelos órgãos competentes da gestão municipal anterior (1984-1987). Porém, segundo relatório da Associação de Geógrafos Brasileiros (AGB) de 1989, no projeto aprovado originalmente, apenas $20 \%$ da vegetação seria preservada, em três parques (dois públicos e um particular) e o uso democrático do espaço ficaria seriamente comprometido, bem como a função ambiental da área seria totalmente descaracterizada.

O processo de negociação da Lubeca com a Prefeitura do Município de São Paulo para a liberação das obras se arrastou por cerca de oito anos, e mesmo com o resultado final favorável à implementação do projeto por essa empresa ${ }^{7}$, ela acabou por desistir do empreendimento e pôs o terreno à venda. A área em questão, porém, tinha um preço muito alto, dadas as suas dimensões e localização no vetor de maior valorização imobiliária do município, com o agravante de que o potencial comprador deveria também assumir as obrigações assinadas pela Panamby Empreendimentos com a prefeitura, além daquelas assumidas com as concessionárias públicas, como a provisão da rede de energia, de água, de esgoto e de iluminação, o que restringia o rol de eventuais interessados ${ }^{8}$.

Dadas as dificuldades em questão, em 1995 foi lançada a ideia de formação de um Fundo 
de Investimento Imobiliário para reunir os capitais necessários para a concretização do negócio, tendo à frente de tal iniciativa os Bancos Bradesco e BRASCAN S.A. Com a organização do Fundo Imobiliário, o terreno foi vendido sob forma de propriedade fiduciária ao Banco Brascan S. $A^{9}$ em 1995 por $\mathrm{R} \$ 61.950 .000,00$. É bom ter em conta que nesse ano a moeda brasileira era equivalente ao dólar (chegando um real a valer mais que um dólar no mercado de câmbio), ou seja, o terreno, na época, custou mais de 60 milhões de dólares. Além do alto preço, os custos estimados, em 1994, pela Panamby Empreendimentos para a execução das obrigações assinadas com o Município (recuperação da vegetação, construção de um viaduto e de uma passarela para pedestres, manutenção e equipamento dos parques e construção da creche) e com as concessionárias de serviços públicos (água, esgoto, gás, iluminação pública, energia elétrica, águas pluviais) chegavam a $\mathrm{R} \$ 3.870 .000,00$.

Dessa forma, a solução encontrada pelos agentes do mercado imobiliário e financeiro para a aquisição do terreno da antiga Chácara Tangará foi a constituição de um Fundo de Investimento Imobiliário reunindo capitais de investidores institucionais, principalmente os Fundos de Pensão. Tratava-se de uma verdadeira inovação no mercado imobiliário, na medida em que as barreiras colocadas pela propriedade da terra e pelo processo de regulamentação do empreendimento foram levantadas pelo capital financeiro autonomizado, dando lugar a um ambicioso projeto imobiliário e urbanístico.

Assim, foi criado o Fundo de Investimento Imobiliário (FII) Panamby em janeiro de 1995, sendo registrado junto à CVM (Comissão de Valores Imobiliários) com um lançamento de $\mathrm{R} \$$ $67.118 .400,00$ em cotas, tendo por finalidade a aquisição do terreno em caráter de propriedade fiduciária pelo administrador do fundo, o Banco BRASCAN S.A., e o custeio da provisão da infraestrutura e dos equipamentos previamente negociados com a administração municipal e com as concessionárias de serviços públicos às quais foram feitas referências anteriormente. A área adquirida foi dividida em duas grandes partes (que já constavam do projeto da empresa que vendeu o terreno ao FII): uma maior, destinada ao que se pode chamar de Bairro Panamby com um "mix" de utilização imobiliária (edifícios residenciais, de escritórios, centro comercial e hotel) e outra menor, destinada à formação de um condomínio fechado vertical, o Villagio de Panamby.

O desenvolvimento imobiliário da área objeto do FII se deu através de seu desmembramento em lotes que foram (e estão sendo ainda) objeto de incorporações para fins residenciais e comerciais, "sob a responsabilidade de empreendedores imobiliários de primeira linha" (PANAMBY, 1995, p. 2). O loteamento do Bairro Panamby é dividido em 3 glebas: na gleba $A$, que não foi vendida ainda, há 12 lotes. Na gleba B, eram originalmente 4 lotes, depois os empreendedores que os compraram os desdobraram em seis, pois a partir do momento em que o FII vende a gleba, o comprador pode desmembrar ou remebrar os terrenos como achar melhor. E na gleba C há 13 lotes.

O retorno do investimento dos cotistas do Fundo Imobiliário ocorre mediante a da venda dos lotes do terreno aos incorporadores interessados em realizar empreendimentos na área, sob a modalidade de permuta por unidades que foram ou serão construídas e/ou em moeda corrente (à vista ou a prazo). Como foi apurado nas entrevistas realizadas, na prática a forma mais comum de relacionamento entre o FII e as incorporadoras se dá através de uma participação nas vendas por parte do Fundo, ou seja, a cada apartamento vendido pela incorporadora há um percentual que vai para o FII, sendo tal repasse controlado pelo banco BRASCAN. Dessa forma, as cotas vão sendo parcialmente amortizadas na proporção em que o FII for realizando financeiramente os investimentos feitos no empreendimento.

No projeto original, quando do lançamento do FII, ficou estabelecido no "plano diretor" do Bairro Panamby, que dos setes setores em que a área fora desmembrada inicialmente, quatro teriam destinação residencial (33,9\% da área do terreno), dois para projetos comerciais $(21,4 \%)$ e um para hotelaria $(3,1 \%)$. Comprovou-se que tal divisão dificilmente se manterá, pois dadas 
algumas dificuldades de concretização do plano inicial, todo o empreendimento deve se voltar para a produção residencial, com exceção do hotel. Já o Villagio de Panamby foi concebido como uma área exclusivamente residencial num terreno de $230 \mathrm{mil} \mathrm{m}^{2}$ sob a forma de condomínio fechado vertical, cercado por muro de alvenaria com altura de $2,4 \mathrm{~m}$ e sensores de presença em toda a sua volta. Segundo o prospecto de lançamento do fundo junto à CVM (PANAMBY, 1995), 76\% do terreno do Villagio foram destinados a áreas verdes e livres para lazer e esporte, somente $9 \%$ seriam ocupados pelas ruas internas e os restantes $15 \%$ pelas edificações, com a construção de no máximo 15 edifícios residenciais e um clube com $33.000 \mathrm{~m}^{2}$ de terreno e 8.460 $\mathrm{m}^{2}$ de área construída. Embora faça parte do FII Panamby, o Villagio não faz parte da área envolvida nas negociações com a administração municipal, ou seja, para a sua comercialização não há as mesmas obrigações a que a área do Bairro Panamby esteve sujeita.

O FII Panamby, já no seu prospecto de lançamento junto à CVM, anunciava que a proposta do projeto urbanístico Panamby / Villagio de Panamby seria a "transformação de uma área, com total respeito à natureza, visando melhorar a qualidade de vida" (PANAMBY, 1995, p. 12). Segue afirmando que dadas as características da área em questão (localização em área nobre, tamanho e proximidade ao centro de São Paulo) foi exigido um detalhado estudo de sua utilização, que culminou com um plano diretor de urbanização extremamente preocupado com a preservação do verde, chegando a afirmar em tal prospecto que "ocupar é preciso, preservar é fundamental". Ou seja, o discurso oficial do empreendimento deixou de lado o conflito envolvendo o capital e o poder público no âmbito ambiental, transfigurando as obrigações assumidas em ato voluntário do FII panamby.

Das negociações anteriores com a administração municipal ficou estabelecida a formação de parques públicos com a vegetação totalmente preservada com uma área de 138.279 $\mathrm{m}^{2}$, além de áreas de preservação permanente dentro dos lotes privativos e da arborização das áreas a serem ocupadas. Assim, o apelo à "natureza" (ou melhor, a uma representação da natureza), muito comum nos anúncios imobiliários na metrópole paulistana, encontra no Panamby uma de suas maiores expressões. Dentre as áreas verdes do empreendimento, destaca-se o Parque Burle Marx, com cerca de $138 \mathrm{mil} \mathrm{m}^{2}$, inaugurado em 1995 e sob gestão de uma Fundação, a Fundação Aaron Birmann, o que o diferencia, em certa medida, de outros parques da cidade, diretamente sob a administração municipal.

\section{É interessante notar que todo o processo} de negociação envolvendo a preservação da vegetação ressurge no discurso que consta no prospecto do fundo e nos anúncios envolvendo o Panamby e o Villagio Panamby como uma preocupação exclusiva dos novos proprietários do terreno, incorporando a ideia de preservação da "natureza" nas estratégias de marketing do fundo e dos incorporadores. Tal estratégia foi muito bem sucedida, pois o grande diferencial do Bairro Panamby (incluindo o Villagio de Panamby) é justamente a presença de uma significativa área verde, representada, sobretudo, pelo Parque Burle Marx, como se pode observar nos anúncios ofertando imóveis em suas imediações, seja nos jornais, seja nas placas publicitárias encontradas no local.

A exploração do marketing do contato com a natureza tornou-se o ponto forte do Panamby, chegando a extremos, como a campanha realizada pela Gafisa, que durante um domingo distribuiu em alguns semáforos da cidade tubos de ar supostamente engarrafado no Villagio Panamby, para que as pessoas pudessem "saborear" um ar puro em meio à poluição da metrópole (O Estado de São Paulo, 29/07 /2003).

Uma questão levantada por estudos realizados sobre o parque Burle Marx seria o seu caráter público ou privado ${ }^{10}$, na medida em que este é administrado por uma fundação que imporia uma série de normas restritivas ao seu uso, como a proibição de jogar bola, andar de bicicleta, patins ou skate, tocar música etc., o que poderia ser interpretado como uma forma de disciplinar o uso da área e restringir sua atratividade para a população mais pobre, que 


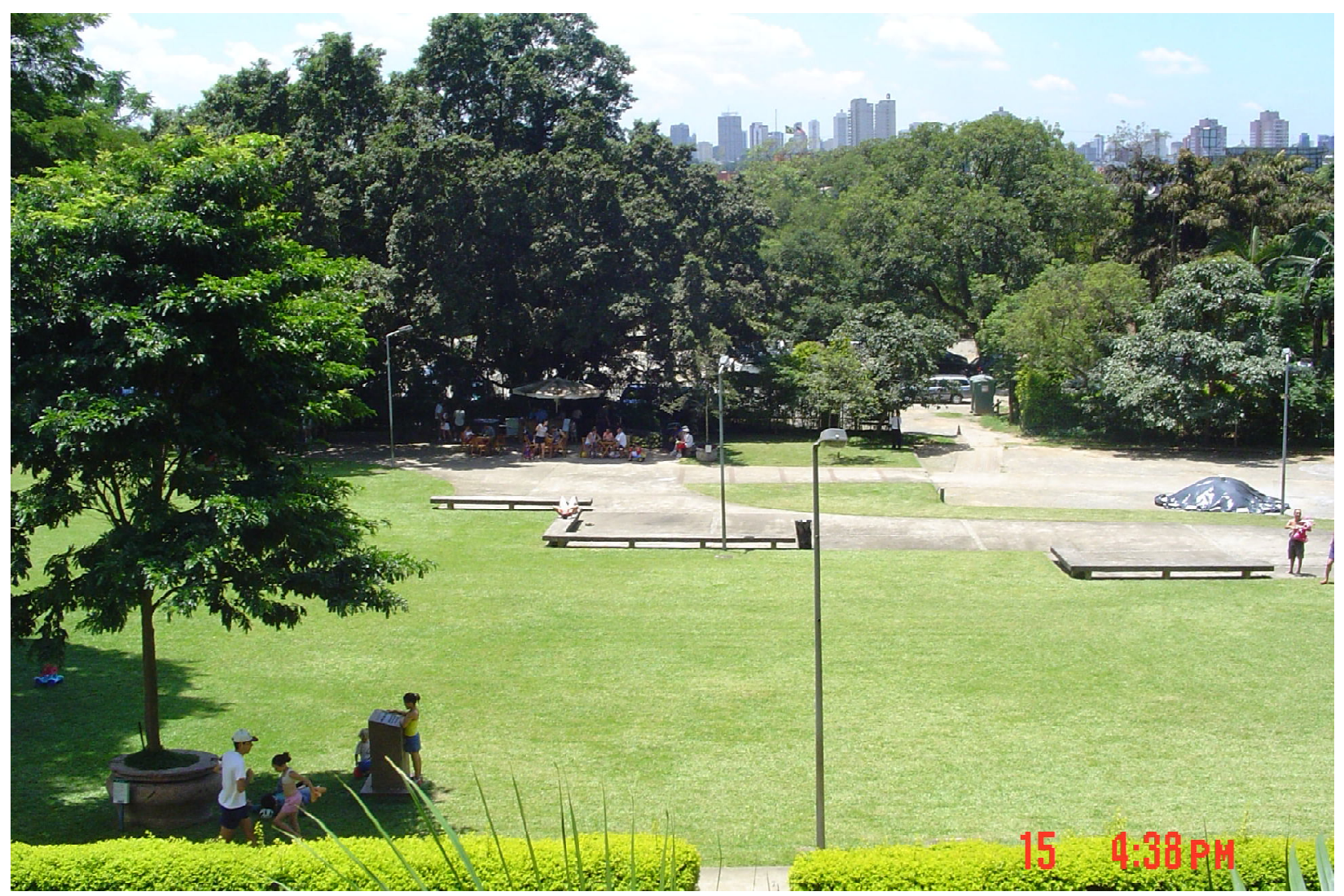

Panorama do Parque Burle Marx. Foto do autor - 15/01/2005.

pouco ou nada teria ali a fazer. Para os moradores entrevistados e para os administradores do parque e do FII Panamby, o parque foi concebido desde o seu início como uma "área contemplativa", sendo essa a principal razão das proibições.

Além da série de restrições e a estrita vigilância (privada) para sua observação no interior do parque, outros elementos podem ser apontados para o baixo uso deste por parte da população das imediações: o difícil acesso por transporte público, o estacionamento pago e o seu relativo isolamento das áreas mais pobres da região. Tais elementos inibidores ao uso mais amplo por parte da população em geral o tornariam uma área quase que exclusiva para aqueles que moram nos apartamentos do Bairro
Panamby, o que reforçaria, de certa forma, o apelo de marketing do empreendimento, pois a área verde seria "exclusiva" para os moradores de seu entorno.

O Panamby foi concebido desde o seu início como um empreendimento urbanístico voltado para o mercado residencial de alto padrão (com uma média de quatro suítes e quatro vagas na garagem, variando de 160 a $400 \mathrm{~m}^{2}$ cada apartamento, além de contarem com equipamentos como piscinas, quadras, academia de ginástica etc.). Tal opção teria se dado por causa da liquidez do mercado para uma camada de renda mais alta e também porque essa camada de renda independe de financiamento para a compra do imóvel, dada a escassez de linhas de financiamento para outros segmentos do 
mercado. Além disso, a localização do empreendimento também foi um fator que pesou para a escolha do público alvo, já que se trata de uma área servida por poucas linhas de ônibus, com poucos serviços e comércio local.

Dessa forma, um aspecto espacial marcante do Panamby é a sua característica de "bairro exclusivo" para uma população de renda elevada localizado entre áreas de favela com população extremamente pobre (favela de Paraisópolis e Peinha). A solução adotada pelos incorporadores atuantes no Panamby foi o isolamento de seus empreendimentos da vizinhança imediata por intermédio da construção de muros, grades e outros aparatos de segurança.

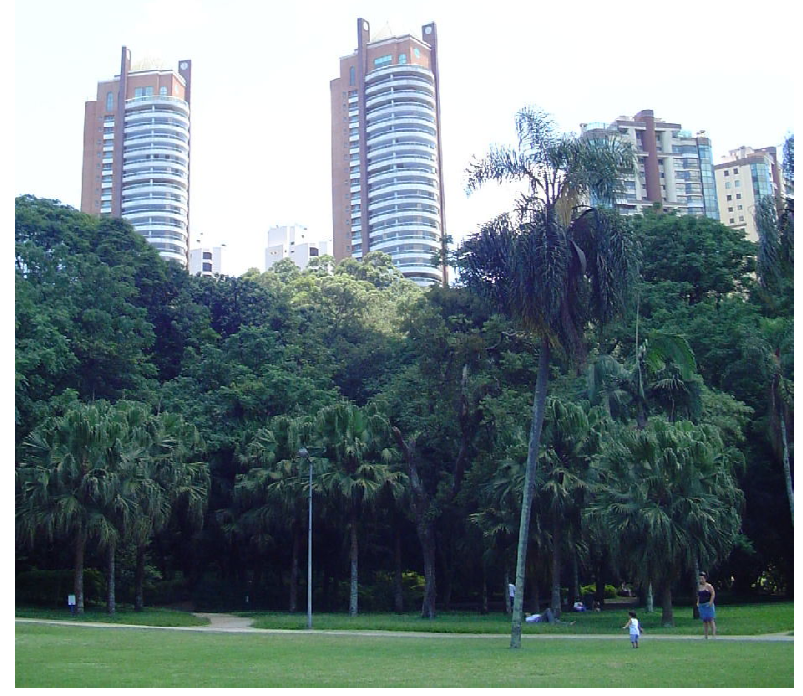

Edifícios de alto padrão do Panamby Foto do autor - 15/01/2005
Enquanto as áreas do Panamby e Villagio de Panamby foram concebidas com toda a infraestrutura urbana necessária, as áreas de favela são desprovidas dessa infraestrutura, são áreas onde a violência é grande, onde os níveis educacionais da população residente são baixos e onde a propriedade fundiária não existe, o que predomina é a posse, e apesar de a favela de Paraisópolis já ser consolidada, os seus moradores não possuem nenhuma segurança legal que garanta o uso das casas onde vivem.

A pobreza não está distante das áreas de moradia da população rica, mas embora a distância física seja pequena, a distância socioeconômica é enorme, causando uma série de problemas de convivência, sendo o principal deles a segurança. A grande incidência de "sequestros relâmpago" foi responsável por uma mobilização dos moradores, que se reuniram ao redor da Associação dos Moradores do Panamby (oficialmente denominada Associação Cultural e de Cidadania do Panamby, fundada em julho de 2001) para a criação de uma força de vigilância paralela à oficial, de forma a coibir as práticas criminosas nas imediações. Tal projeto de segurança contou com a assessoria da administradora do fundo de investimento imobiliário (a BRASCAN Imobiliária) e com o aporte financeiro das principais incorporadoras atuantes na área (ou que ainda não atuam), como a Cyrela, a Camargo Corrêa S.A. (proprietária do Shopping Jardim Sul, que fica próximo ao Panamby, e proprietária de terrenos nas imediações deste), a Company S.A., a América Properties, a Falanga Empreendimentos, a Koema-SincoMac, a Klabin-Segall e o Fundo Panamby. A parte de logística do projeto tem sua sede em um hipermercado e todos os edifícios contam com uma ligação de Nextel ${ }^{11}$ entre si e com as viaturas de vigilância. Segundo uma moradora militante na Associação, após a implementação do projeto os níveis de criminalidade do Panamby caíram, enquanto os índices para quase toda a cidade subiram, o que atestaria o sucesso do projeto. Não se pode deixar de notar o interesse, tanto do administrador do Fundo Panamby quanto das incorporadoras, em 
minimizar o problema, já que uma divulgação de problemas envolvendo a segurança do local poderia atuar no sentido de sua desvalorização.

Além da ação no campo da segurança, a Associação de Moradores do Panamby também busca uma aproximação com os moradores das favelas mediante o diálogo com lideranças e da implementação de projetos sociais. Além do diálogo com as lideranças da favela de Paraisópolis, há uma ação direta em outra favela próxima conhecida como Peinha por meio de projetos socioeducacionais. Em parceria com a Associação dos Moradores do Panamby nesses projetos atuam a Paróquia Santa Edwiges, o Colégio Pentágono, além de empresas e profissionais voluntários de diversas áreas que contribuíram com espaço, recursos financeiros e humanos para o desenvolvimento das atividades.

Dessa forma, os moradores do Panamby buscam solucionar o problema da segurança por intermédio da integração com o entorno e da criação de uma organização de segurança paralela à estatal, já que por se tratar de uma ilha rica em meio à pobreza generalizada, e por mais que os edifícios tenham controles internos, a segurança dos moradores seria um dos pontos fracos do empreendimento.

Além do problema da segurança, os atuais moradores e as incorporadoras consideram que o adensamento de edifícios e o significativo aumento de moradores no Bairro Panamby e imediações pode ter como consequência um inconveniente: o aumento dos congestionamentos no interior e adjacências do empreendimento, dada a escassez de vias de saída para outras áreas da cidade. Segundo apurado, a A Associação de Moradores buscou uma aliança com as grandes incorporadoras atuantes nas imediações do Panamby para pressionar a Câmara dos Vereadores de São Paulo a modificar o Plano Diretor Municipal com a finalidade de incorporar os projetos viários reivindicados por eles.

Apesar desses pontos negativos, a marca Panamby pode ser considerada como um sucesso enquanto empreendimento imobiliário, sendo atualmente utilizada para denominar áreas próximas e que não fazem parte do projeto oficial ou do Fundo de Investimento Imobiliário. O uso da marca Panamby pelos incorporadores não ligados ao FII revela a atração que ela exerce sobre o mercado, indicando o seu sucesso.

Os fatores desse sucesso seriam, em primeiro lugar, a existência da área verde, o grande chamariz para futuros moradores. Em segundo lugar, a localização no eixo de valorização imobiliária da cidade, o vetor sudoeste, onde se encontram áreas residenciais de alto padrão no Morumbi e áreas de expansão dos centros comerciais e de negócios ao longo de avenidas (Avenida Faria Lima, Av. Eng. Luis Carlos Berrini, Av. Água Espraiada, Av. Marginal do Rio Pinheiros etc.). Em terceiro lugar, o projeto urbanístico, voltado para os consumidores de alto padrão, contribuiu para reafirmar o caráter exclusivo do empreendimento, consolidando a sua valorização. Em quarto lugar, a existência de uma infraestrutura viária prévia (as avenidas mencionadas e a Marginal do Rio Pinheiros), bem como centros de negócios (Centro Empresarial localizado na Marginal do Rio Pinheiros, o Centro Berrini etc.), shoppings centers (Jardim Sul, Morumbi, Marketplace etc.), escolas de renome, hospitais de primeira linha, entre outros fatores de atração.

Por outro lado, observou-se que tal área, alvo de disputa entre a parcela da sociedade que desejava seu tombamento e transformação em parque público em sua totalidade e os incorporadores imobiliários, acabou, por meio de uma solução de compromisso entre a prefeitura e os agentes do mercado, por transformar-se em uma área residencial de alto padrão, quase que exclusiva para seus moradores, acentuando o processo de fragmentação, homogeneização, hierarquização e segregação socioespacial existente na cidade de São Paulo.

\section{O Mutirão City Jaraguá}

Tradicionalmente, a principal forma de provisão habitacional adotada no Brasil, em decorrência da ação do binômio BNH/SFH, foi a de produção de novas moradias por parte de 
empreiteiras contratadas pelas companhias habitacionais. Tratou-se, antes de tudo, de viabilizar o processo de acumulação na construção civil, sendo que a provisão de moradias baratas e de boa qualidade ficou praticamente em segundo plano nas prioridades do Estado. Segundo Nabil Bonduki:

Os padrões impostos pelo BNH e pela Caixa Econômica Federal (CEF) a partir de 1964 consolidaram uma visão distorcida do problema da moradia, que beneficiava a construção civil e se disseminou por todo o país, acumulando uma série de equívocos: gestão centralizada e autoritária; não participação popular e do usuário na concepção dos projetos e programas; não utilização de recursos a fundo perdido; critérios de financiamento bancários, e não sociais; adoção da casa própria como única forma de acesso à moradia; desprezo pelo projeto arquitetônico e urbanístico, com clara preferência por soluções uniformizadas e padronizadas; opção por grandes conjuntos localizados na periferia das cidades, estimulando a especulação imobiliária; e absoluto distanciamento entre a produção habitacional pública e as práticas informais, que garantem a produção da cidade real, onde a maioria da população mora (BONDUKI, 2000, p. 102).

Em contraposição à forma de produção habitacional tradicional, dominada pela relação público-privado (Estado e empreiteiras), a forma de construção baseada no binômio mutirão/ autogestã $\mathrm{O}^{12}$ mostrou-se eficiente no combate a muitos dos problemas gerados pela primeira.

A principal característica da forma mutirão/autogestão é a relação que se estabelece entre o poder público, a demanda por moradia e o chamado terceiro setor. Cabe ao poder público fiscalizar e financiar a obra, e à demanda, representada pela associação comunitária, realizar tanto a sua gestão quanto participar de sua produção, cabendo a ela também a contratação da assessoria técnica que a auxilia no processo construtivo e no gerenciamento. Trata-se de uma forma de garantir maior liberdade de escolha do projeto, do processo construtivo e de gerenciamento da obra, de acordo com as necessidades e anseios dos futuros moradores, criando condições para uma maior autonomia dos mutirantes (WERNA et al., 2001).

A forma mutirão/autogestão distancia-se do mero fornecimento de mão-de-obra por parte dos futuros moradores para o barateamento da construção e da reprodução da força de trabalho, principal motivo de críticas a essa modalidade de produção (ROYER, 2002; MARICATO, 1982; OLIVEIRA, 2003). Estima-se que a autogestão, por meio de ações como compra de materiais, contratação de empresas para executar etapas da obra, fiscalização financeira etc., resulta em uma redução de custo total da obra da ordem de 30 a $40 \%$. Já a redução de custo total da mãode-obra, resultante da efetiva participação dos moradores no trabalho braçal de construção, seria de apenas 10\% (WERNA et al., 2001). Ou seja, mais do que a "autoconstrução", o que gera a maior eficiência da provisão habitacional por mutirão é a "autogestão".

Tendo em vista questões como o preço, a qualidade e o tempo de produção da moradia, a prática do mutirão/autogestão é mais conveniente para o poder público do que a produção por empreiteira, conforme conclusão obtida em estudo realizado por Werna et al. (2001) para a Região Metropolitana de São Paulo. Dentre os casos analisados pelo estudo ${ }^{13}$, os que apresentaram menores custos médios de construção, sendo mais eficientes em termos financeiros, foram os mutirões realizados tanto pela CDHU, quanto pela Cohab-SP.

No caso do município de São Paulo, as primeiras formas de provisão habitacional por mutirão/autogestão datam da primeira metade da década de 1980 (ARANTES, 2002), consolidando-se como alternativa de política habitacional apenas na administração municipal do PT na gestão de Luiza Erundina (1989-1992). Nessa administração, o programa de mutirões autogeridos foi implementado pela Superintendência de Habitação Popular, como forma de se contornar as resistências da tecnoburocracia entrincheirada na Cohab-Sp, que representava, em certa medida, os interesses das 
empreiteiras e do modelo proveniente do binômio SFH/BNH. A gestão dos recursos foi transferida para os mutirantes e a atuação dos arquitetos militantes foi regulamentada mediante a constituição de organizações não-governamentais, "o que deu aos escritórios de arquitetos que trabalhavam com os movimentos [de moradia] um novo caráter, mais profissional, e novas ambigüidades, relacionadas à emergência do chamada terceiro setor" (ARANTES, 2002, p. 188).

Durante a administração municipal de 1989-1992, foram firmados 84 convênios com associações comunitárias de construção, atendendo a cerca de 11 mil famílias (BONDUKI, 2000). Nessa gestão foi criado o Programa de Construção de Unidades Habitacionais em Mutirão e Autogestão, também chamado Funaps Comunitário. Mas apenas duas mil unidades foram finalizadas na gestão 1989-1992 e as outras nove mil passaram para a administração seguinte.

Porém, com a eleição de Paulo Maluf (1993-1996) e de Celso Pitta (1997-2000) para a prefeitura de São Paulo, o programa de mutirão foi interrompido, devido a questões políticas e de interesses econômicos envolvendo empreiteiras e a prefeitura, sendo deixadas muitas casas sem conclusão e muitos contratos firmados com as associações comunitárias simplesmente não foram cumpridos. Por intermédio de inúmeras práticas, como o não repasse de verbas, a exigência de uma série de medidas burocráticas e o questionamento da demonstração de contas dos mutirões, a gestão Maluf buscou paralisar o programa, apesar de seu aparente sucesso em promover moradia de qualidade a um preço razoável.

Somente com a gestão de Marta Suplicy entre 2001 e 2004 é que o programa de mutirões foi retomado de forma sistemática e prioritária pela administração municipal, agora sob a administração da Cohab-Sp. Porém questiona-se se foi realmente intenção da segunda administração petista a retomada dos mutirões, tal como se deu na gestão 1989-1992. A centralização das ações na Cohab-Sp, os vultosos recursos liberados para a construção de moradias por empreiteiras se comparados aos destinados aos mutirões, a burocracia e lentidão para o repasse dos recursos aos mutirões, a dificuldade em regularização da propriedade das moradias quando entregues aos futuros moradores, são alguns dos elementos que podem levar ao questionamento da prioridade dada pela cúpula da administração municipal para essa forma de provisão de moradia e sobre a viabilidade da produção em regime de autogestão em larga escala, apesar da dedicação dos funcionários municipais envolvidos com a execução dos projetos.

Com os oito anos de administração da direita no município de São Paulo (1992-2000), os movimentos por moradia, sem espaço de negociação na administração municipal, passaram a pressionar o poder público estadual, nas gestões do PMDB e PSDB. Em 1990, a União Nacional dos Movimentos por Moradia (UNM) obteve do governo Fleury (PMDB) um programa de mutirões autogeridos, sendo então mantido no governo Covas com outra denominação e acabou sendo progressivamente alterado, de forma a atrelar as associações de mutirantes que dele participavam aos interesses do PSDB, na tentativa de formar uma base popular de sustentação a esse partido (ARANTES, 2002). Entretanto, o programa de mutirões deixou de ser priorizado em benefício das obras realizadas por empreiteiras sob uma nova modalidade, conjugando a construção de habitações com a intermediação das construtoras na compra e venda de terras, o que deu margem à práticas ilícitas, que culminaram na descoberta de uma série de irregularidades, levando à queda do presidente da CDHU em 2000 (ARANTES, 2002).

No âmbito da CDHU, a prática do mutirão/ autogestão nunca foi assumida como carro chefe da provisão habitacional (ROYER, 2002), apesar das vantagens em custo final da moradia e em área construída. Problemas relativos à adaptação do corpo técnico à prática de autogestão, que implica compartilhar informações e poderes com os mutirantes e falta de vontade política podem ser apontados como os grandes entraves para uma afirmação do mutirão/autogestão dentro da CDHU. 
Tendo em vista as diferenças entre as duas Companhias Habitacionais com relação ao regime de mutirão/autogestão e a prioridade que cada uma delas deu a esse regime de construção, a pesquisa priorizou o estudo dos mutirões geridos pela Cohab-Sp, pois no momento em que foi realizada, esta era a Companhia que priorizava, entre seus objetivos, o regime de autogestão, enquanto que a CDHU parecia, segundo o que foi apurado ao longo da pesquisa, não possuir um objetivo bem definido com relação a esse regime de provisão habitacional.

Dentre as práticas de autogestão, destaca-se a participação dos mutirantes na definição do projeto, no controle financeiro e orçamentário, na compra de materiais e contratação da empresa de assessoria técnica e empreiteiras, formando uma tríade que envolve a associação de moradores, a assessoria técnica e as empreiteiras, sob a supervisão da CohabSp.

Com relação à definição do projeto pelos mutirantes, a parceria com a assessoria técnica é fundamental, pois é com base nessa parceria que o projeto nasce e é executado. Segundo Maria Isabel Cabral ${ }^{14}$, da Assessoria Técnica Ambiente (que foi a escolhida pela associação de moradores para a construção do Mutirão City Jaraguá), o projeto é discutido com os futuros moradores, mas em certa medida a Assessoria se reserva o direito de manter alguns padrões técnicos estabelecidos de antemão.

O programa, além de ser importante pela participação da população na definição do projeto, na execução da obra e no controle financeiro, tem a característica de contar com subsídios explícitos para a população de menor renda, o que torna a moradia mais acessível aos mais pobres.

Por outro lado, alguns questionamentos são geralmente feitos à forma do mutirão. O principal seria o prazo de produção das moradias, que pode ser extremamente longo, desarticulando o mutirão como forma de associação de moradores. Mas, segundo Bonduki (2000), problemas tais como um prazo longo para a realização da obra, grande aparato administrativo, gestão não democrática por parte de algumas lideranças etc. não são relativos ao mutirão em si, mas sim à forma como podem ou não ser geridos. Pode ocorrer tanto uma má gestão como uma boa gestão no mutirão. E o que as experiências revelaram até o momento é que a boa gestão (por meio da autogestão) predomina na forma mutirão, apesar dos entraves burocráticos existentes.

Uma importante contribuição para a maior eficiência dos mutirões é justamente o envolvimento dos mutirantes nas associações de moradores, o que é conseguido pela forma como são selecionados, que é feita por um sistema de pontuação que leva em conta a participação nas assembleias, reuniões e manifestações do movimento por moradia. Ou seja, os contemplados devem passar por um processo de conscientização política e luta pela moradia para poder ter acesso a um lugar no mutirão/ autogestão a ser desenvolvido.

Com relação à localização dos mutirões, eles ainda repetem a lógica que empurra os pobres para a periferia, como pôde ser observado ao longo da pesquisa realizada. Tal fato decorre da existência de um estoque de terrenos nessas áreas, de propriedade da Cohab ou da Prefeitura (destacando-se o extremo leste do município), ou devido ao menor custo de desapropriação dessas áreas, o que é um fator relevante para a efetivação dos financiamentos compatíveis com a renda da demanda, composta por parcelas de baixa renda da população.

Uma outra crítica, muito pertinente porque feita no interior da própria União Nacional dos Movimentos por Moradia (UNM) por um dos seus coordenadores ${ }^{15}$, diz respeito à forma de financiamento e comercialização das moradias, pois a moradia, como hoje é discutida, refere-se à efetivação da propriedade privada e não a um direito coletivo. A percepção da moradia como propriedade é uma das causas que leva à escolha dos terrenos baratos por parte do Movimento, pois são esses os que seus associados podem efetivamente pagar.

O Mutirão City Jaraguá localiza-se no extremo noroeste do município de São Paulo, no 
distrito de Jaraguá, na Sub-Prefeitura de Pirituba, próximo à Estrada de Taipas. Trata-se de um terreno desapropriado em 1990 (gestão Erundina) pela prefeitura. De acordo com a Cohab-Sp, esse terreno pertencia a um loteamento aprovado em 1977 pela Anastácio Empreendimentos Imobiliários, Participações e Representações Ltda., sendo uma parte dele residencial, e outra, industrial, que teria o nome de Loteamento City Jaraguá. Como tais empreendimentos não foram implementados, a área destinada à parte residencial foi desapropriada em 1990 (inicialmente uma área de $468.445 \mathrm{~m}^{2}$ ), mas depois se verificou que dentro da área desapropriada havia uma área de proteção florestal, que já havia sido desapropriada antes. Por isso, foi feita uma revisão na desapropriação, e a área final ficou em 381.429 $\mathrm{m}^{2}$. Trata-se de uma grande gleba onde foram construídos muitos conjuntos habitacionais anteriores ao mutirão City Jaraguá, que ocupa uma parcela da área originariamente desapropriada.

Somente no final do governo de Celso Pitta (1997-2000) é que a prefeitura assinou um termo de compromisso com os representantes do Movimento dos Sem-Teto da Zona Oeste (ligado à UNM) para a construção de moradias no local, mas as obras somente tiveram início no ano de 2003 (gestão Marta Suplicy). Segundo a coordenação do Movimento dos Sem-Teto da Zona Oeste ${ }^{16}$, o City Jaraguá, como entidade jurídica, foi criado em 1999, e as famílias escolhidas pelo movimento para o loteamento tomaram posse efetiva do terreno (para limpar, cercar, garantir o posse contra ocupações por outras famílias, etc.) no início de 2001 . As primeiras famílias mudaramse para suas casas no City Jaraguá em setembro de 2004, antes da conclusão das obras, como forma de assegurar a posse das casas pelos mutirantes e garantir a integridade física do condomínio frente aos roubos de material de construção efetuados pelos moradores do entorno. Porém, além das razões alegadas pela Cohab e pela coordenação dos mutirantes, a proximidade das eleições municipais acelerou a ocupação das casas pelos futuros moradores, seja como forma de propaganda política, seja como reação à possível derrota de Marta Suplicy que buscava a reeleição ${ }^{17}$.
Na organização do mutirão/autogestão há uma divisão do trabalho entre a Cohab, os mutirantes e a Assessoria Técnica. Segundo a Cohab-Sp, coube a esta companhia realizar a terraplenagem e a infraestrutura do loteamento: redes de água e esgoto, arruamento e pavimentação. E a responsabilidade da associação de moradores do mutirão foi a de construir as 180 casas previstas no projeto com o apoio da Assessoria Técnica Ambiente - Trabalhos para o Meio Habitado, que cuidou da parte técnica, com a contratação de empreiteiros para as obras mais especializadas, além do gerenciamento financeiro e geral da obra. Das 180 casas do projeto, 174 são sobrados unifamiliares e 6 são casas térreas para uso de famílias com necessidades especiais. O custo estipulado da construção de cada casa foi de R\$ 22 mil, para uma área construída de 64 $\mathrm{m}^{2}$. Os recursos para a construção vieram, via Cohab, do Fundo Municipal de Habitação.

O financiamento da venda das moradias foi feito pela própria Cohab às famílias, sendo o valor das prestações cobradas de acordo com a renda familiar, o que incluía a possibilidade da existência de subsídios de até $50 \%$ do valor integral. Esse fato possibilitou a inclusão no programa de famílias com rendimentos inferiores a 3 salários mínimos. As parcelas do financiamento serão reajustadas de acordo com um índice elaborado pela Cohab, que busca cobrir a inflação do período, mas que é inferior aos índices utilizados pelo financiamento bancário, em geral.

Com relação à organização do trabalho no City Jaraguá, o primeiro ponto a ser destacado é o relativo à autogestão. $O$ trabalho de organização dos moradores pelo movimento e pela assessoria técnica começou bem antes das obras, em 1999. Entre 1999 e 2002, segundo a arquiteta responsável pelo projeto do City Jaraguá, Maria Isabel Cabral, foram realizadas reuniões periódicas, chegando a dez reuniões mensais para a preparação dos moradores e atualização da parte técnica. Nessas reuniões foi desenvolvido o projeto dos sobrados, definidos os métodos de construção e foram feitas estimativas dos custos da obra. 
Com relação ao trabalho na obra, este foi dividido entre os moradores e as empreiteiras contratadas. As famílias colaboraram no mutirão durante os finais de semana e feriados, das 8 até às 17 horas, divididas em grupos $(A, B, C)$, trabalhando ora em regime de rodízio, ora simultaneamente em distintas atividades no interior do mutirão. Essas famílias, durante seus dias de trabalho, realizavam tarefas mais simples, que não requeriam conhecimentos ou práticas específicas, como o trabalho de concretagem, a escavação, o reaterro, a limpeza, o transporte de materiais, etc. A força de trabalho dos mutirantes representaria cerca de $10 \%$ do trabalho total do mutirão. Os mutirantes seguiram um "Estatuto de Obras", onde foram listados os regulamentos a serem seguidos e foram estabelecidos os casos de justificativa de faltas, as penalidades aos faltosos, a organização das tarefas, os horários de trabalho e parada, etc. Esse estatuto é padronizado para todos os mutirões ligados à Cohab-Sp e foi realizado em conjunto com as associações de mutirantes.

Em entrevistas realizadas com alguns mutirantes, ficou claro o importante papel da mulher no movimento, pois foram as mulheres, no interior de suas famílias, as que sempre acreditaram na possibilidade de o mutirão dar certo. Muitos dos maridos, irmãos ou demais parentes do sexo masculino não acreditavam no mutirão e em sua organização, baseada em reuniões e assembleias, pois achavam que era uma "enrolação", perda de tempo.

A mão-de-obra especializada é contratada pelo mutirão a uma empreiteira para a realização dos trabalhos técnicos e que requerem algum grau de conhecimento e especialização, o que sem dúvida agiliza o andamento da obra e melhora a sua qualidade final. Ocorreram sérios problemas envolvendo um empreiteiro, o que acabou por atrasar as obras. Isso custou tempo e dinheiro ao mutirão, já que ocorreram furtos realizados pelos trabalhadores contratados e a obra ficou paralisada por algum tempo, devido ao não pagamento de salários aos empregados contratados pela empreiteira, o que revela que um dos pontos fracos da divisão do trabalho no mutirão/autogestão é o da contratação dos empreiteiros, tendo em vista que ao longo da obra foram utilizados três empreiteiros diferentes.

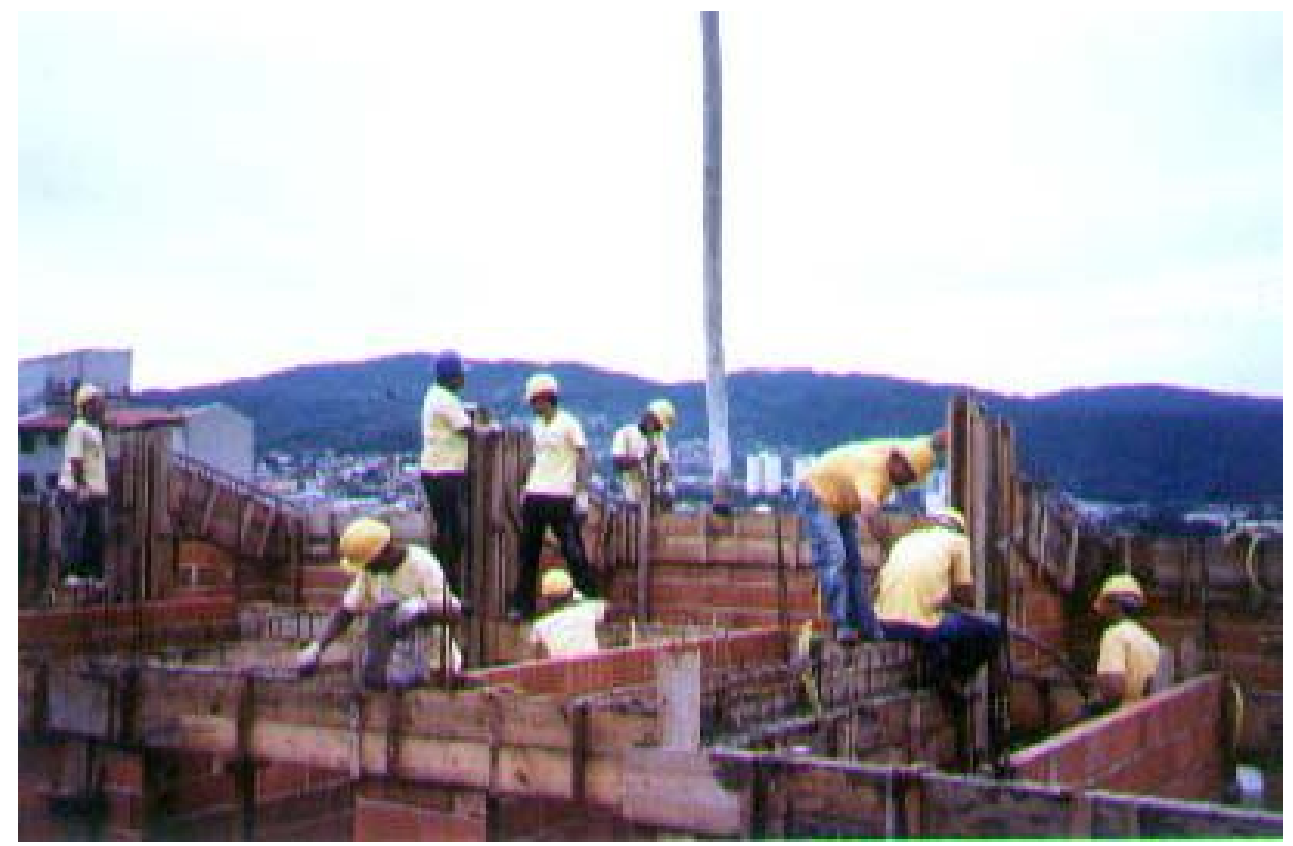

Mutirantes trabalhando em obra do City Jaraguá. Foto do autor - 13/09/2005. 
Com o início da construção das casas, as famílias, organizadas em torno da associação de mutirantes, em conjunto com a Assessoria Técnica, geriram as obras e as finanças do empreendimento por intermédio de uma Coordenação e da realização de assembléias e reuniões. Por meio do trabalho das comissões e da assessoria os mutirantes vão organizando as tarefas semanais e planejando o andamento da obra. Mas tal forma de agir não está livre de algumas contradições. De acordo com Fábio $\mathrm{Kahn}^{18}$, arquiteto envolvido no projeto do City Jaraguá, o estabelecimento de uma Coordenação Geral e de algumas coordenações paralelas acaba por hierarquizar as relações de trabalho no mutirão. E, segundo ele, ao longo do processo de construção, choques entre as coordenações e a Assessoria Técnica foram comuns revelando até uma disputa pelo poder decisório, o mesmo ocorrendo entre os mutirantes, o que para a Coordenação do Mutirão City Jaraguá foi considerado como algo normal, tendo em vista que se tratava de processo que envolve muitas pessoas.

Além das reuniões para o planejamento e execução da obra, houve também as assembleias para prestação de contas e avaliação do cronograma físico da obra, do que dependiam as liberações de recursos junto à Cohab. Um aspecto diferenciador do City Jaraguá com relação a outros mutirões é que ao final das assembleias realizadas no canteiro de obras, que posteriormente tornouse o centro comunitário, ocorria a projeção de filmes num telão, o que era uma oportunidade rara para a maioria das pessoas presentes de ver uma obra cinematográfica de qualidade, bem como um momento de integração entre os mutirantes.

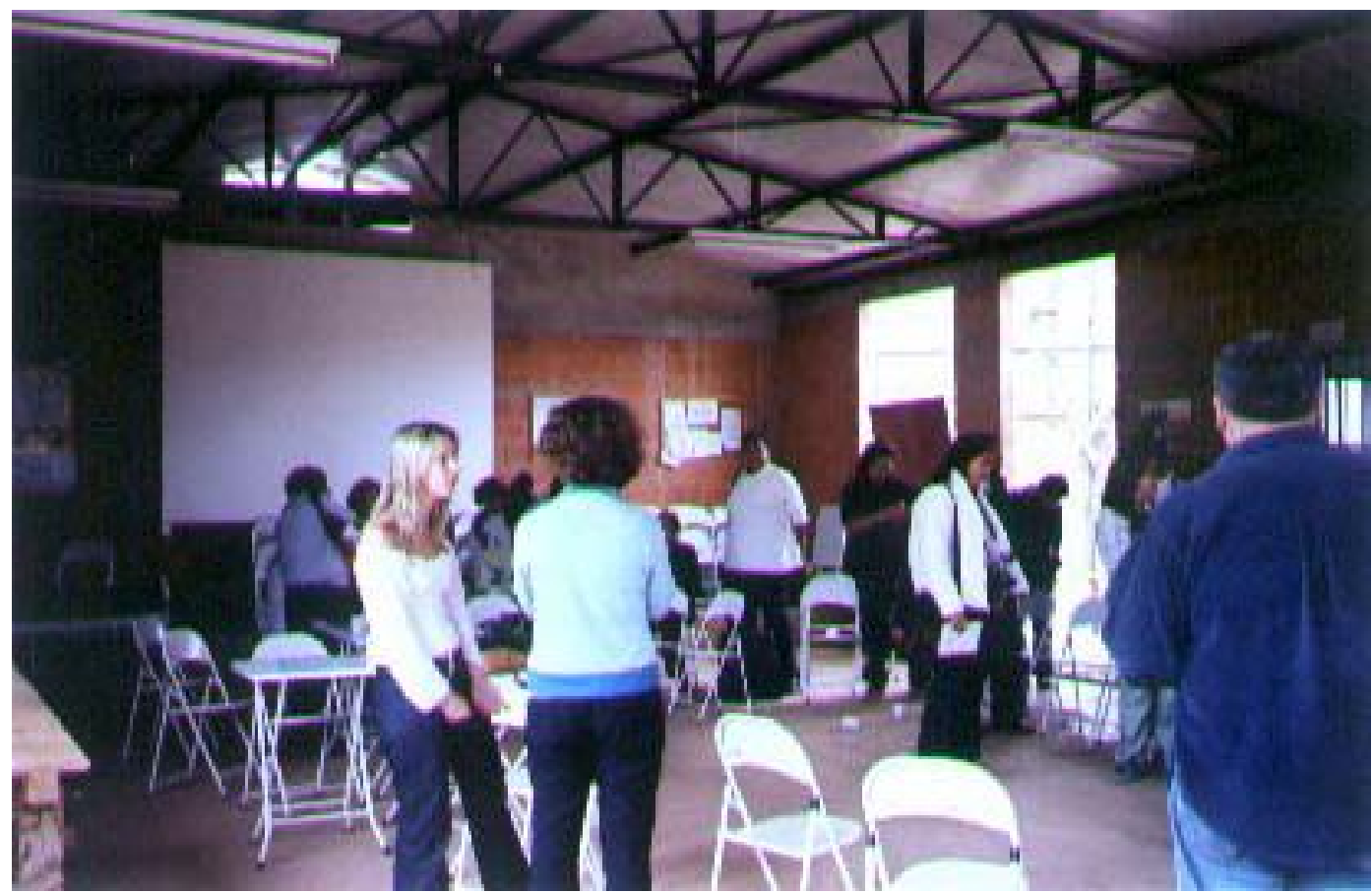

Centro Comunitário do Mutirão City Jaraguá - Antigo canteiro de obra. Foto do autor - 11/12/2003 
Um aspecto interessante observado diz respeito à diferenciação existente entre o loteamento Mutirão City Jaraguá e as edificações do entorno, frutos de distintos projetos da prefeitura e da Cohab-Sp. Em geral são prédios de apartamentos, com menor área construída, existindo também casas autoconstruídas a partir de um "embrião", com qualidade muito inferior às do mutirão. Além das moradias ligadas à provisão feita pelo poder público, há nas proximidades áreas de favelas e de loteamentos irregulares com casas feitas por autoconstrução. Tendo em vista tal diversidade, chama a atenção, quanto à fragmentação do espaço, o cercamento do mutirão com grades e portões, dando um aspecto de "condomínio fechado" da periferia.

Tal separação é percebida pelos moradores, e alguns tentam transpor as possíveis separações existentes com ações de integração envolvendo os moradores do entorno, como reforço escolar para as crianças, formação de grupos de teatro, capoeira e evangelização. Mas em alguns momentos a tensão entre o interior do condomínio e o exterior se manifesta, seja na destruição das grades que rodeiam o mutirão, seja na reclamação dos moradores com relação ao comércio informal, sobretudo bares clandestinos, instalados na frente do mutirão, além dos furtos de materiais de construção atribuídos aos vizinhos.

Outro aspecto importante diz respeito à localização do City Jaraguá. Trata-se de uma área distante da centralidade de São Paulo, com poucas opções de emprego, consumo e lazer, repetindo o padrão histórico de localização da provisão habitacional pelo Estado, apesar de ser uma área que conta com transporte coletivo (ônibus e trem), o que minimiza, de certa forma, o isolamento dos moradores. Os entrevistados ressaltaram a falta de opções de comércio e a necessidade de buscar trabalho em áreas distantes do Mutirão, mas destacaram positivamente o transporte (linhas de ônibus ligando o condomínio aos terminais Cachoeirinha e Pirituba) e a infraestrutura de ensino. Para eles, no momento em que as entrevistas foram realizadas, o maior problema era a recusa da companhia telefônica de instalar uma ligação que possibilitasse aos moradores ter acesso às linhas da empresa, o que gerava uma sensação de isolamento com relação ao resto da cidade, criando uma dificuldade para o contato com os parentes, com o emprego, com os órgãos públicos (sobretudo a polícia) e com os amigos.

Para os moradores do City Jaraguá, a conquista da casa própria, mediante lutas no movimento de moradia e do trabalho no Mutirão é mais importante do que a localização da área. Todos os entrevistados acreditam que foi uma conquista muito importante a obtenção de uma casa, apesar das dificuldades enfrentadas ao longo dos anos de lutas, reivindicações, reuniões e trabalho no mutirão. Para a Coordenação do mutirão, além da casa, um outro aspecto importante deve ser ressaltado, o da construção da cidadania.

Mas, apesar disso, o fim da obra pode representar o fim da mobilização dos moradores e o aumento da individualização e privatização da vida no condomínio, efeito causado pela obtenção da propriedade privada e particular, fato ressaltado por uma moradora do City.

A construção de moradias por intermédio do mutirão/autogestão é um processo complexo, que envolve distintos agentes (Estado, Movimentos de Moradia, Assessoria Técnica, futuros moradores, empreiteiros, trabalhadores contratados) com interesses que nem sempre coincidem. É uma alternativa para a população com menores rendimentos, não somente pela possibilidade de obtenção de um subsídio, mas também pela qualidade das moradias e pelo processo de formação dos mutirantes enquanto cidadãos. Porém, o mutirão/autogestão é uma opção política do poder público, e a alternância no poder municipal e estadual tem como efeito a sua descontinuidade ou retomada, dependendo do partido político no controle da administração pública. Além disso, há os interesses das empresas da construção civil, que em algumas ocasiões manifestaram seu desacordo com relação à forma mutirão/autogestão. Assim, o futuro dessa alternativa de provisão habitacional 
ainda é incerto, apesar do reconhecimento crescente de sua eficiência e eficácia econômica e social.

\section{Considerações Finais: a fragmentação espacial e a autossegregação nos dois casos estudados.}

Examinamos inicialmente um caso de uma forma sofisticada de relação entre o setor imobiliário e o capital financeiro, o Fundo de Investimento Imobiliário Panamby, responsável por um empreendimento de alto padrão para as camadas mais abastadas da população paulistana. Em seguida, foi examinada uma forma tradicional, mas ao mesmo tempo inovadora, de provisão habitacional da população de baixa renda, o mutirão, mediante a análise do caso do City Jaraguá. Os dois casos analisados guardam contradições internas e entre si. Porém, como são dois casos inseridos no processo mais amplo de produção do espaço urbano da metrópole, guardam semelhanças que à primeira vista são encobertas pela grande diferenciação de localização, de padrão construtivo, de relação com o capital financeiro e com o Estado, bem como de nível socioeconômico de seus moradores.

Nos dois casos, a fragmentação do espaço urbano se observa por meio do isolamento dos empreendimentos com relação ao seu entorno. Através da observação e de entrevistas realizadas com moradores tanto do City Jaraguá quanto do Panamby, constatou-se a existência de uma sensação de isolamento, uma percepção de diferença e estranhamento com relação aos morados das proximidades. A percepção de isolamento se traduz fisicamente pela autossegregação, materializada na construção de grades e muros que isolam os empreendimentos de seu entorno nos dois casos analisados. No caso do Panamby, além dos muros, sistemas de segurança e vigilância privados, compostos por guardas, câmeras e sistemas de comunicação são utilizados pelos seus moradores como forma de se prevenirem contra eventuais ameaças à parcela mais abastada da população. A "solução" encontrada, tanto pelos moradores dos condomínios de alto padrão do Panamby quanto pelos antigos sem-teto do City Jaraguá é a autossegregação, como se pode ver nas imagens abaixo:

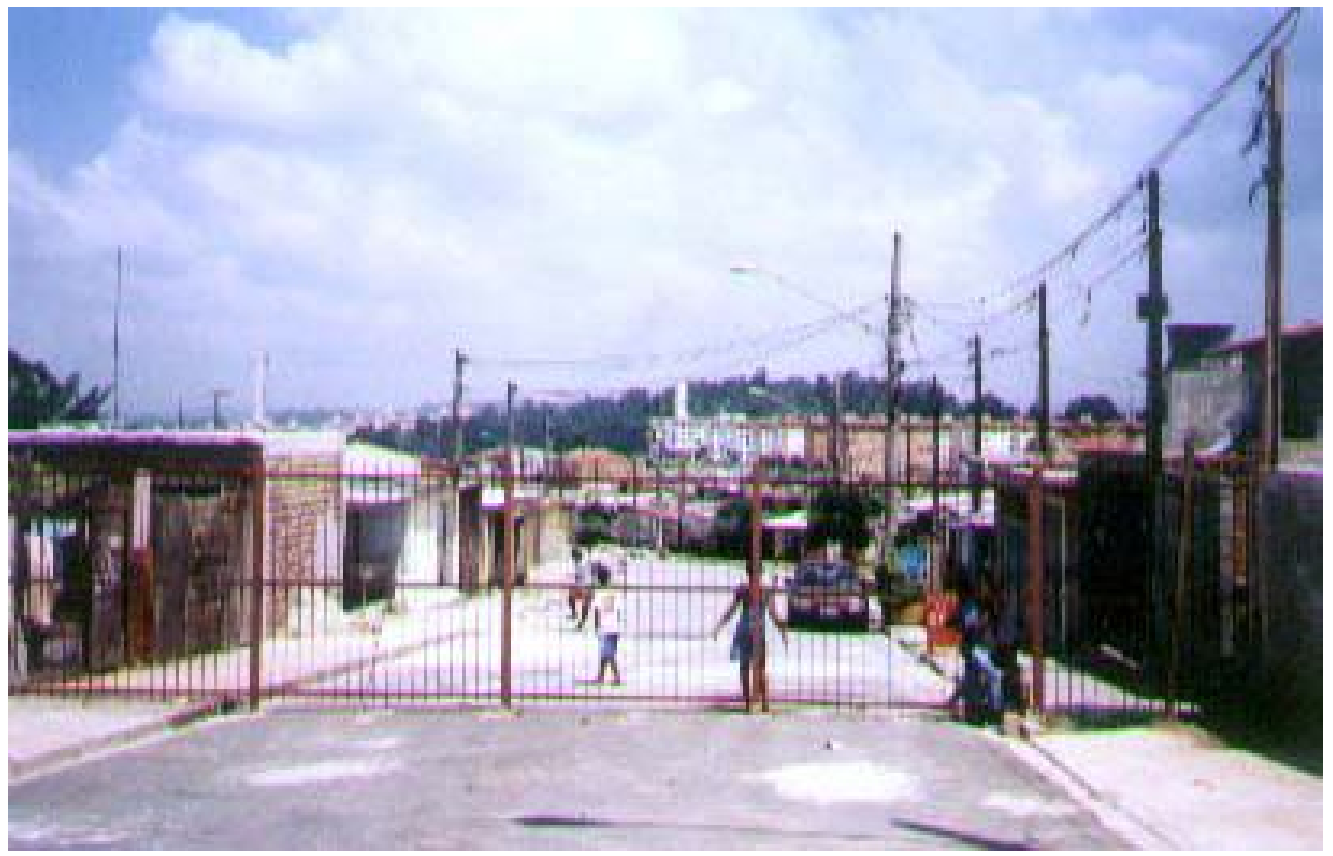

Grade separando o Mutirão City Jaraguá das casas de seu entorno Foto do autor - 05/02/2005 
Dois lados da mesma moeda:

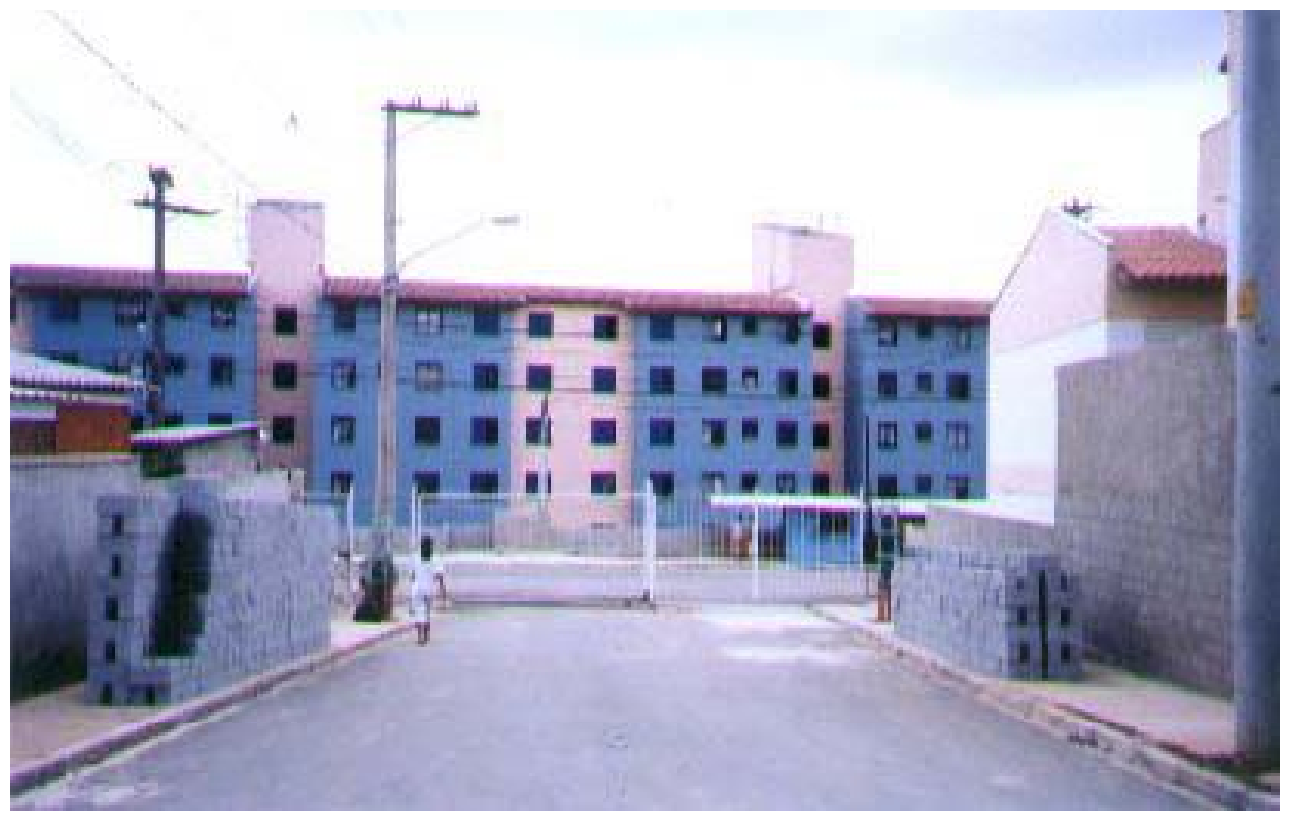

Portão da entrada principal do Mutirão City Jaraguá, atrás se vê conjunto construído pela CDHU, Foto do autor - 05/02/2005.

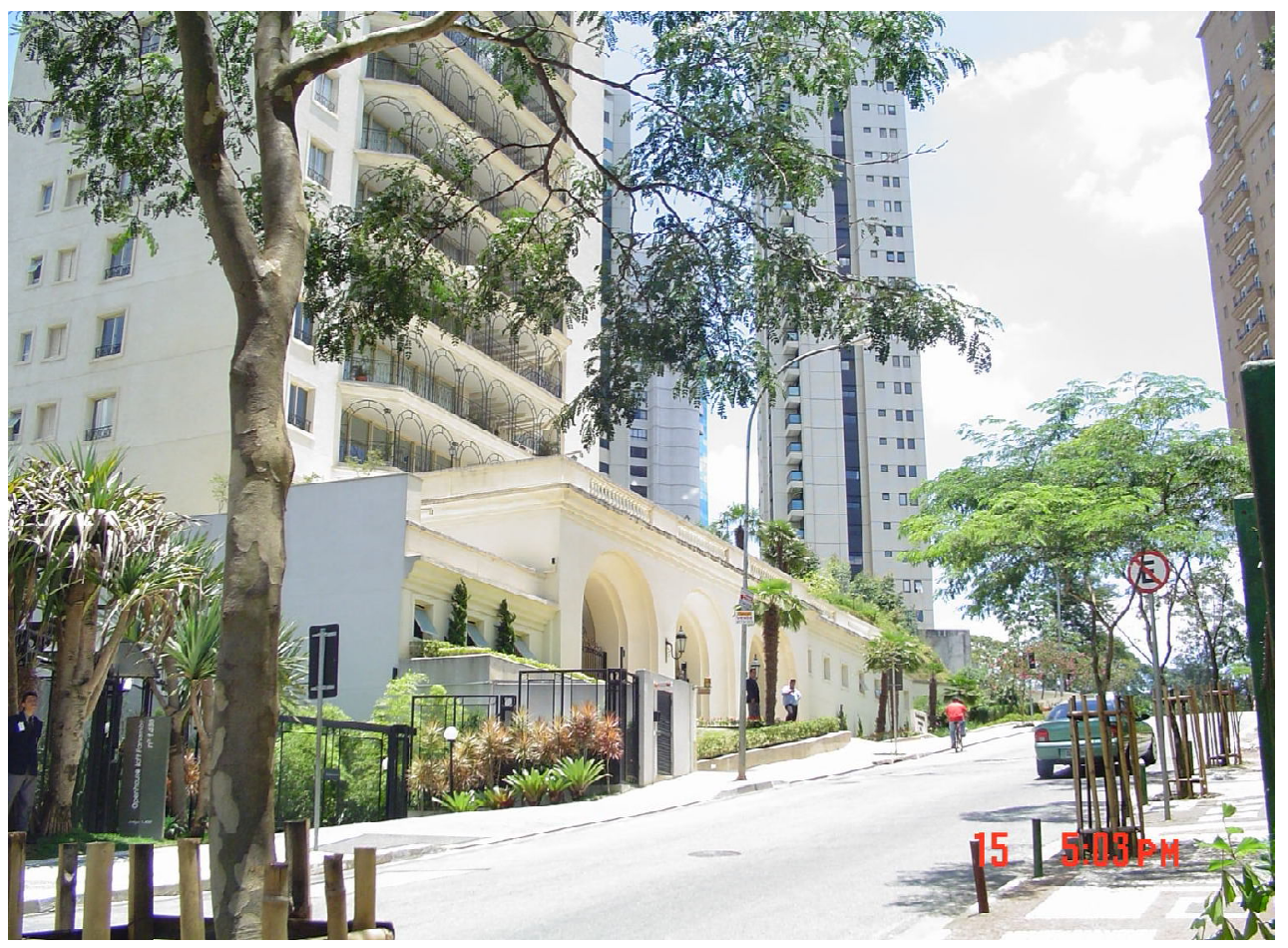

Entrada de um dos edifícios do bairro Panamby. Foto do autor - 15/01/2005 
Com relação à hierarquização do espaço, observamos nos dois casos que os moradores dos empreendimentos se consideram como iguais, seja em termos socioeconômicos, como no caso do Panamby, seja em termos de pertencerem ao movimento social organizado, como no caso do City Jaraguá. O espaço de cada um dos empreendimentos é visto como "melhor" que o dos moradores ao redor, ou seja, hierarquicamente superior. Tal percepção é acentuada pelas diferenciações físicas dos empreendimentos em relação ao seu exterior imediato. O Panamby é composto por edifícios de alto padrão, rodeado por favelas. O City Jaraguá é composto por casas de tipo sobrado, sendo rodeado por conjuntos habitacionais verticais ou por casas autoconstruídas, além de áreas de favela. Porém, em termos socioeconômicos, os moradores do City Jaraguá se assemelham aos seus vizinhos, e uma boa parte deles vieram de favelas e cortiços antes de conseguirem suas casas no mutirão.

Tanto a associação de Moradores do Panamby quanto alguns moradores do City Jaraguá buscam alguma integração com os ocupantes do entorno com a finalidade de minimizar as ameaças reais ou imaginárias à sua segurança. Aulas de reforço e grupos de teatros são estratégias usadas nos dois casos. Mas, no caso do Panamby, ao lado das medidas socioeducativas, um forte aparato de segurança privada foi instalado pelos condomínios do empreendimento, intimidando os pedestres e limitando a livre circulação daqueles que não são pertencentes à "vida normal" da vizinhança (moradores e trabalhadores domésticos e dos edifícios).

O isolamento, porém, é sentido de forma diferenciada pelos moradores dos dois empreendimentos. No caso do Panamby, seus habitantes buscaram áreas mais isoladas do que consideram o caos urbano, marcado pela poluição, o trânsito engarrafado, a miséria e a criminalidade. O contato com uma forma de representação da natureza materializada no parque Burle Marx também expressa essa busca de uma anticidade no urbano. A impossibilidade desse isolamento é motivo de preocupação para a maior parte dos moradores de um empreendimento como o Panamby. Já o isolamento para os moradores do City Jaraguá significa o dificuldades de acesso à centralidade da metrópole, com a consequente restrição às possibilidades de emprego, consumo e lazer. A falta de ligação telefônica acentuava, para a maior parte dos moradores, essa sensação de um isolamento involuntário com relação aos seus parentes, conhecidos e também às positividades do urbano. O isolamento para eles também acentuava a sensação de insegurança, já que parte dos moradores do City Jaraguá se sentem rodeados por uma vizinhança hostil.

Por fim, um outro aspecto pode ser explorado: o individualismo e a retirada para a vida no lar são comuns aos dois empreendimentos. No caso do Panamby, o nível de sociabilidade é restrito pela falta de vida nas ruas. O parque Burle Marx, que poderia ser uma área de sociabilização importante é antes uma área de contemplação individual e de uso exclusivo dos moradores dos edifícios mais próximos, dadas as rígidas restrições impostas ao seu uso. O ritmo de vida da rotina imposta à maior parte dos seus moradores é outro elemento que limita o uso do parque, pois apesar de ser um chamariz fundamental nas estratégias de marketing imobiliário, o parque é pouco frequentado pelos moradores do Bairro Panamby. No caso do Mutirão City Jaraguá, apesar da existência de um Centro Comunitário e do histórico de luta e organização de seus moradores, parece ter ocorrido uma desmobilização após a conquista do objetivo geral, a casa própria. Segundo foi apurado com base nas entrevistas realizadas, muitos dos moradores veem nas atitudes de seus vizinhos do empreendimento um recolhimento para a vida privada e a busca de soluções individuais para os problemas enfrentados.

Assim, buscamos explorar, por intermédio dos dois exemplos analisados, a ideia de que a lógica de reprodução do capital, mediada pela propriedade privada, domina a lógica de reprodução dos diferentes grupos sociais, em 
maior ou menor grau, independentemente de seu nível de renda, direcionando suas percepções e vivências com relação ao espaço que habitam. 0 resultado, entre outros, é a produção de um espaço marcado pela fragmentação, homogeneização, hierarquização, bem como pela segregação. A utopia lefebvriana de um urbano marcado pela reunião e pela troca parece cada vez mais distante com a crescente materialização da separação e da divisão entre os indivíduos. Porém, há sempre a possibilidade de produção de um outro espaço. A autogestão dos mutirantes do City Jaraguá é um exemplo dessa possibilidade, que mesmo que seja submetida ao contexto maior de relações capitalistas, é um pequeno passo no caminho da produção de um espaço que, nos termos de Lefebvre (2000), seja menos um produto do capital e mais uma obra de seus habitantes. Cabe aos seus moradores, e somente a eles, reconquistar através do uso a casa que lhes foi tomada.

\section{Notas}

${ }^{1}$ Artigo enviado em fevereiro de 2007 . O presente artigo baseia-se nas pesquisas realizadas para a preparação da Tese de Doutorado do Programa de Pós-Graduação em Geografia Humana da Faculdade de Filosofia, Letras e Ciências Humanas da Universidade de São Paulo, chamada $O$ financiamento e a financeirização do setor imobiliário: Uma análise da produção do espaço e da segregação sócio-espacial na cidade de São Paulo através do estudo do mercado da moradia, sob orientação da Profa. Dra. Margarida Maria de Andrade, defendida em setembro de 2005. Gostaria de expressar aqui meus agradecimentos à Profa. Margarida pela dedicada orientação dada ao longo dos quase quatro anos de pesquisa e redação da Tese. A tese em questão encontra-se no prelo para ser publicada pela editora AnnaBlume com o título de $O$ urbano em fragmentos: a produção do espaço e da moradia através das práticas do setor imobiliário.

${ }^{2}$ Lefebvre ao discutir o consumo produtivo do espaço parte do conceito de Marx de consumo produtivo, atualizando, porém, esse conceito. Ele amplia o conteúdo do conceito original para dar conta da problemática urbana e da reprodução das relações de produção no modo capitalista de produção contemporâneo. Para Marx (1989), o consumo produtivo ocorre quando o trabalhador, aplicando sua força de trabalho sobre os meios de produção, transforma-os em produtos de valor maior que o desembolsado pelo capital. Ocorre, portanto, consumo tanto da força de trabalho quanto dos meios de produção no processo produtivo. 0 consumo produtivo se opõe ao consumo individual. Esse último ocorre quando o capitalista ou o trabalhador emprega o dinheiro para a satisfação de suas necessidades pessoais.

${ }^{3} \mathrm{O}$ fenômeno dos condomínios fechados no Brasil foi estudado no livro de Maria Teresa Pires do Rio Caldeira, Cidade de muros - crime, segregação e cidadania em São Paulo (São Paulo: Editora 34 / Edusp, 2000). Para o caso dos condomínios e comunidades fechadas nos Estados Unidos, ver, por exemplo, Blakely, E. J. and Snyder, M. G. Fortress America - Gated Communities in the United States. Massachusetts: The Brookins Institution Press, 1999. O caso argentino pode ser analisado em Svampa, Maristella. Los que ganaron: La vida en los countries y barrios privados - Buenos Aires: Editorial Biblos, 2001. Para um artigo sobre a questão da segregação urbana ver Marcuse, Meter. No caos, sino muros: el postmodernismo y la ciudad compartimentada, In: Ramos, A. M. (Org.), Lo Urbano. Barcelona: Edicions UPC, 2004.

${ }^{4}$ Para um quadro geral e dramático da situação de moradia dos mais pobres no mundo ver DAVIS (2006).

5 Tal terreno fora adquirido pela Light em 1945 no bojo de suas prerrogativas de preferência de compra das terras situadas na linha de enchentes do rio Pinheiros. Para mais detalhes sobre a atuação da Light em São Paulo, em especial sua atuação no mercado imobiliário, ver a fundamental tese de Seabra (1987). 
${ }^{6}$ Segundo Rafael Birmann. Entrevista concedida em 21/02/2005.

${ }^{7}$ No acordo realizado no início de setembro de 1989, entre a administração municipal e a Lubeca, ficou decidido que a empresa cederia ao Município uma área para uso institucional de $24.110,78 \mathrm{~m}^{2}$ e para parques de $138.279,22 \mathrm{~m}^{2}$, bem como recuperaria o jardim desenhado por Burle Marx, plantaria mudas de árvores na Administração Regional de Campo Limpo, cercaria com grades o futuro parque, e construiria uma creche padrão de 600 $\mathrm{m}^{2}$ em outra área (Longo, 26/09/89; Ata da Reunião entre a Lubeca e Grupo de Trabalho da Prefeitura do Município de São Paulo, 04/09/1989). Porém a empresa obteve o direito de computar o equivalente da área doada no cálculo do coeficiente de aproveitamento no que excedia às doações obrigatórias por Lei para qualquer empreendimento de grande porte, bem como a alteração da posição do viaduto projetado para a via de ligação desde a Estrada do Morumbi até a Marginal do Rio Pinheiros. Em 31 de agosto de 1993, já na administração municipal de Paulo Maluf (1992-1995), foi assinado um Termo de Assunção entre a prefeitura e a Panamby Empreendimentos Ltda. (nome assumido pela empresa responsável pelo projeto em 1993, sucedendo a Lubeca no empreendimento), no qual os termos do acordo estabelecido com a prefeitura foram oficializados. Em 08 de agosto de 1994, a creche de $600 \mathrm{~m}^{2}$ teve sua localização definida, sendo construída na Favela Água Branca, entre a Marginal esquerda do Tietê e a Avenida Marquês de São Vicente, sendo, na prática, parte do Cingapura construído na área, obra de maior visibilidade política da gestão do prefeito Paulo Maluf.

${ }^{8}$ Como relatou a arquiteta ligada ao atual proprietário do empreendimento (o Fundo de Investimento Imobiliário Panamby), Maria Olide. Entrevista concedida em 19/01/2005.

${ }^{9}$ Por propriedade fiduciária entende-se o regime de propriedade no qual o adquirente se compromete a manter em separado de seu patrimônio anterior o bem adquirido, não o integrando ao seu ativo. Dessa forma, tal bem não faz parte da lista de bens e direitos para fins de liquidação judicial ou extrajudicial do adquirente, não podendo ser dado em garantia de débito de operação do adquirente, não sendo também passível de execução por quaisquer credores.

${ }^{10}$ Ver, por exemplo, BURGOS (2003).

${ }^{11}$ Segundo a publicação da Associação Cultural e de Cidadania do Panamby, os rádios Nextel instalados nas portarias dos condomínios participantes "permitem comunicação com os patrulheiros, de forma que se um morador, no trajeto estabelecido no contrato, sentir-se inseguro por qualquer circunstância e a qualquer hora, poderá solicitar à portaria de seu Edifício, via celular, um patrulheiro para acompanhá-lo".

${ }^{12}$ Entende-se por autogestão na produção da moradia um processo de gestão do empreendimento habitacional em que os futuros moradores, organizados em associações ou cooperativas, administram a construção das unidades habitacionais em todos os seus aspectos, a partir de regras e diretrizes estabelecidas pelo poder público, quando este participa financiando o empreendimento (Bonduki, 2000, p. 35).

13 Os casos analisados por Werna et. al. foram: CDHU - Mutirão; CDHU - Empreitada Global; Cohab Mutirão, Cohab - Plano Empresário; Paulicoop Cooperativa; Habi - SP - Cingapura.

${ }^{14}$ Entrevista concedida em 29/09/2004.

${ }^{15}$ Donizeti Fernandes de Oliveira, entrevista concedida em 19/10/2004.

${ }^{16}$ Elaine Ferreira Rosa, entrevista concedida em 07/ $12 / 2004$.

17 A prefeita Marta Suplicy perdeu a eleição para o candidato do PSDB, José Serra.

${ }^{18}$ Arquiteto ligado à assessoria técnica e que trabalhou na obra do City Jaraguá. Entrevista concedida em $18 / 10 / 2004$. 


\section{Bibliografia}

ARANTES, Pedro Fiori. Arquitetura Nova: Sérgio Ferro, Flávio Império e Rodrigo Lefévre, de Artigas aos mutirões. São Paulo: Editora 34, 2002.

ASSOCIAÇÃO CULTURAL E DE CIDADANIA DO PANAMBY. Notícias do Panamby. Out-Nov. 2004, Edição 08 - Ano 01; e Dez. 2004 - Edição 09 Ano 01, 04p.

BONDUKi, Nabil. Origens da habitação social no Brasil - Arquitetura Moderna, Lei do Inquilinato e Difusão da Casa Própria. São Paulo: Estação Liberdade: FAPESP, 2000.

BURGOS, Rosalina. Parques públicos urbanos na metrópole paulistana : concepção e uso na produção do espaço urbano. São Paulo, 2003. Dissertação (Mestrado em Geografia). Departamento de Geografia, FFLCH, USP.

CARLOS, Ana Fani Alessandri. São Paulo: do capital industrial ao capital financeiro. In: CARLOS, Ana Fani A.; OLIVEIRA, Ariovaldo Umbelino de (Orgs.). Geografias de São Paulo: $A$ metrópole do século XXI. São Paulo: Contexto, 2004.

CONDEPHAAT. Processo de Tombamento da Chácara Tangará. n. 27.096/89.

CORTÁZAR, Julio. Casa Tomada. In: Cuentos completos - 1. Madrid: Alfaguara, 1994.

DAVIS, Mike. Planeta Favela. São Paulo: Boitempo Editorial, 2006.

LEFEBVRE, Henri. La survie du capitalisme - la re-production des rapports de production. Paris: Éditions Anthropos, 1973.

De lo rural a lo urbano. Barcelona: Ediciones Península, 1978.

. Une pensée devenue monde - Faut-il abandoner Marx? Paris: Fayard, 1980.

Lógica formal, lógica dialética. Rio de Janeiro: Civilização Brasileira, 1991.
LEFEBVRE, Henri. A Revolução Urbana. Belo Horizonte: Ed. UFMG, 1999.

. A cidade do capital. Rio de Janeiro: DP\&A, 1999(a).

The Everyday and everydayness. In HARRIS, Steven; BERKE, Deborah. Architecture of everyday life. New York: Princeton Architectural Press, 1998, p. 32-37 [tradução do verbete Quotidien et Quotidienneté, para a Encyclopedia Universalis, de 1972].

MARICATO, Ermínia. Autoconstrução, a arquitetura possível. In: MARICATO, Ermínia (Org.). A produção capitalista da casa (e da cidade). São Paulo: Alfa-Ômega, 1982.

MARX, Karl. O Capital, Livro I, Volume1. Rio de Janeiro: Bertrand Brasil, 1989.

OLIVEIRA, Francisco. Crítica à razão dualista . São Paulo: Boitempo, 2003.

PANAMBY. Prospecto de Distribuição de Cotas Representativas do Fundo de Investimento Imobiliário Panamby, março de 1995, 65 p.

ROYER, Luciana de Oliveira. Política Habitacional no Estado de São Paulo: Estudo sobre a Companhia de Desenvolvimento Habitacional e Urbano do Estado de São Paulo, CDHU. São Paulo, 2002. Dissertação (Mestrado). Faculdade de Arquitetura e Urbanismo (FAU), USP.

SEABRA, Odette Carvalho de Lima. Os meandros dos rios nos meandros do poder: Tietê e Pinheiros - Valorização dos rios e das várzeas na cidade de São Paulo. São Paulo, 1987. Tese (Doutorado). Departamento de Geografia, FFLCH, USP.

VELLOSO, R. C. L.. Na vida das ruas. Escrevendo muito depois de Heidegger. In: VITRUVIUS. Textos especiais - janeiro de 2005. Disponivel em: <http://www.vitruvius.com.br/arquitextos/ arq000/esp274.asp, > Acesso em 15 fev. 2007.

WERNA, Edmundo et al. Pluralismo na habitação. São Paulo: AnnaBlume, 2001.

Trabalho enviado em fevereiro de 2007

Trabalho aceito em novembro de 2009 